Michelle C. Turner ${ }^{1}$

Donald T. Wigle ${ }^{1}$

Daniel Krewski ${ }^{1}$
This article was originally published by Environ Health Perspect 118:33-41 (2010).doi:10.1289/ ehp.0900966 available via http://dx.doi.org/ [Online 29 July 2009] and is part of the scientific collaboration between Cien Saude Colet and EHP. Supplemental material is available online (doi:10.1289/

ehp.0900966.S1 via http:// dx.doi.org/).

${ }^{1}$ McLaughlin Centre for Population Health Risk Assessment, Institute of Population Health,

University of Ottawa. One Stewart St., Room 313, Ottawa, ON, Canada K1N 6N5.mturner@uottawa.ca

\section{Residential pesticides and childhood leukemia: a systematic review and meta-analysis}

\author{
Pesticidas residenciais e leucemia na infância: \\ revisão sistemática e meta-análise
}

Abstract It is a systematic review and meta-analysis of previous observational epidemiologic studies examining the relationship between residential pesticide exposures during critical exposure time windows (preconception, pregnancy, and childhood) and childhood leukemia. Searches of Medline and other electronic databases were performed (1950-2009). Study selection, data abstraction, and quality assessment were performed by two independent reviewers. Random effects models were used to obtain summary odds ratios (ORs) and 95\% confidence intervals (Cis). Of the 17 identified studies, 15 were included in the metaanalysis. Exposures during pregnancy to unspecified residential pesticides insecticides, and herbicides were positively associated with childhood leukemia. Exposures during childhood to unspecified residential pesticides and insecticides were also positively associated with childhood leukemia, but there was no association with herbicides. Positive associations were observed between childhood leukemia and residential pesticide exposures. Further work is needed to confirm previous findings based on self-report, to examine potential exposure-response relationships, and to assess specific pesticides and toxicologically related subgroups of pesticides in more detail.

Key words Child, Environmental exposure, Leukemia, Meta-analysis, Pesticides
Resumo Trata-se de uma revisão sistemática e meta-análise de estudos epidemiológicos observacionais anteriores que examinaram a relação entre a exposição de pesticidas residenciais durante as janelas de exposição crítica do tempo (pré-concepção, gravidez e infância) e leucemia infantil. Foram realizadas pesquisas de dados em diversas bases de dados eletrônicas como Medline e outras. Dois revisores independentes realizaram o estudo de seleção, abstração de dados e avaliação da qualidade. Foram utilizados modelos de efeitos aleatórios para obtenção de razões chances (odds ratio) e intervalos de confiança de 95\% (IC). Dos 17 estudos identificados, 15 foram incluídos na metaanálise. A exposição a pesticidas e inseticidas residenciais não especificados durante a infância foi positivamente associada com a leucemia infantil, mas não houve associação com herbicidas. Foram observadas associações positivas entre leucemia infantil e exposição a pesticidas residenciais. São necessários mais estudos para confirmar os resultados anteriores com base no autorrelato, para examinar possíveis relações exposição-resposta, e para a avaliação em detalhes de pesticidas específicos e subgrupos de pesticidas toxicologicamente relacionados.

Palavras-chave Criança, Exposição ambiental, Leucemia, Meta-análise, Pesticidas 
Leukemia is the most common form of childhood cancer in Canada and the United States, accounting for $>30 \%$ of new cancer cases ${ }^{1,2}$. During 2000-2004, there were nearly 1,400 new cases of leukemia among children $0-14$ years of age in Canada, with incidence rates highest among those $0-4$ years of age $e^{2,3}$. Acute lymphoblastic leukemia (ALL) accounts for most $(\sim 80 \%)$ childhood leukemia cases, followed by acute myelogenous leukemia $(\mathrm{AML})^{2}$. Although much progress in treating childhood leukemia has been achieved, treatment entails substantial morbidity, and elevated morbidity and mortality outcomes continue to be observed among survivors compared with children who have not developed the disease $e^{4,5}$.

Acute leukemias are heterogeneous, characterized by different genetic and chromosomal abnormalities, with differing frequency by age ${ }^{6}$. The two-step model for childhood leukemia proposes that leukemia development occurs after both a first mutation, usually a chromosomal translocation occurring in utero, and a second mutation occurring after birth ${ }^{6,7}$. Children with Down syndrome experience has an elevated risk for the disease $^{8,9}$. Although a variety of environmental and chemical exposures have been suggested to play a role in the etiology of the disease, ionizing radiation remains the sole environmental risk factor established to date ${ }^{10}$. Other potential risk factors that have received some attention in the scientific literature include parental smoking and alcohol consumption, electromagnetic field exposure, hydrocarbons, socioeconomic factors, immunity and infection, and pesticides ${ }^{7,10-14}$.

Several studies examining the potential association between childhood leukemia and both parental occupational and residential pesticide exposure have been conducted over the past several decades, with positive associations observed ${ }^{15}$. Partly because of concerns surrounding potential adverse child health impacts, several Canadian provinces and municipalities have recently banned the cosmetic use of pesticides on public or private property ${ }^{16,17}$. Similar bans are also being considered elsewhere.

Residential pesticide use is associated with elevated child exposures. Use of pyrethroid insecticides in the household was found to be a significant predictor of urinary pyrethroid metabolite levels in children in a recent longitudinal study ${ }^{18}$. Child urinary concentrations of two organophosphorus pesticide metabolites (dimethyl and diethyl dialkylphosphate compounds) were found to be higher with parental garden pesticide use but not with pet treatment or indoor pesticide use in a Seattle study ${ }^{19}$.
We conducted a systematic review and metaanalysis of previous observational epidemiologic studies examining the relationship between residential pesticide exposures during critical exposure time windows (preconception, pregnancy, and childhood) and childhood leukemia and explored potential methodological and clinical sources of heterogeneity in results. Although there have been previous reviews, none have included a quan-titative synthesis of the results available to date. Results of an analysis examining the association between childhood leukemia and parental occupational pesticide exposure are presented in a separate, companion review ${ }^{20}$.

\section{Materials and methods}

This systematic review and meta-analysis was conducted according to a protocol designed by M.C.T. and D.T.W.

\section{Literature search}

The search strategy was designed to identify previous observational epidemiologic studies examining the relationship between residential pesticide exposures during critical exposure time windows (preconception, pregnancy, childhood) and childhood leukemia. Preliminary searches using Ovid MEDLINE were conducted to inform the design of the final search strategy detailed below. An information specialist at the University of Ottawa was also consulted in finalizing the search strategy.

The search strategy was first developed to search the Ovid MEDLINE (1950-March week 3, 2009) and Ovid MEDLINE database of in process and other nonindexed citations (1950 to 31 March 2009) and then adapted to search the Ovid EMBASE (Excerpta Medica Database; 1980 to week $132009)^{21}$, TOXNET (Toxicology Data Network) ${ }^{22}$ (through 31 March 2009), OpenSigle (2009) (through 31 March 2009), and ProQuest Digital Dissertations and Theses (2009) ${ }^{23}$ (through 31 March 2009). The following medical subject headings $(\mathrm{MeSH})$ and key words were used:

. Exposure: exp Environmental Exposure/, exp Environmental Pollutants/, exp Pest Control/, exp Pesticides/, pesticid\$.tw, her-bicid\$.tw, insecticid\$. tw, fungicid $\$$.tw

. Population: exp Child/, exp Adolescent/, exp Infant/, child\$.tw, adolescen\$.tw, infant?.tw, newborn?.tw, youth.tw, teenage\$.tw

. Outcome: exp Hematologic Neoplasms/, exp Leukemia/, leuk?emia\$.tw 
Search terms were grouped according to the Boolean operators OR and AND. A complete depiction of the Ovid MEDLINE search strategy is given in Supplemental Material, Table 1 (available online at doi:10.1289/ehp.0900966.S1 via http://dx.doi.org).

All titles and abstracts identified were independently examined by two of us (M.C.T. and D.T.W.) in order to determine their potential suitability for inclusion in the systematic review. After this primary screen, the complete articles were obtained and the inclusion/exclusion criteria applied. Discrepancies were resolved by consensus. No language criteria were applied. Where abstracts were identified or further details required, particularly relating to the designa-tion of pesticide exposure as residential or occupational, the corresponding author was contacted to ascertain further details of the study. In addition to searching the databases listed above, the reference lists of all included studies and journal Web sites were also hand searched; studies identified manually were evaluated in the same manner as above.

\section{Inclusion and exclusion criteria}

Original epidemiologic studies of childhood leukemia using a case-control or cohort design with an assessment of at least one index of residential/household pesticide exposure/use were included here. Reports were excluded if they were review articles, ecologic studies, case reports, cluster investigations, or studies of adults or if they examined residential exposure or proximity to agricultural pesticides. Where there were multiple publications, the most relevant report was retained (usually the most recent).

\section{Data abstraction}

After identification of all relevant studies, data abstraction was performed independently by the same two reviewers (M.C.T. and D.T.W.). A standard data abstraction form was prepared and piloted to collect relevant data related to referencing, study design, subject selection, exposure assessment, statistical analysis, and results. A single exposure index was identified for each original study and, where data were available, each combination of exposure time window and pesticide type (unspecified, insecticides, herbicides).

\section{Quality assessment}

All included studies underwent independent quality assessment by the same two reviewers (M.C.T. and D.T.W.). We used a modified version of the Downs and Black ${ }^{24}$ checklist for the assessment of the methodological quality of randomized and non-randomized studies of health care interventions [Supplemental Material, Table 2 (doi:10.1289/ehp.0900966.S1)]. Before conducting the quality assessment, the two reviewers discussed the individual items on the checklist to clarify their interpretation. No attempt was made to blind the reviewers of the authorship or publication status of the original studies. Differences in quality assessment were resolved by consensus.

\section{Analysis}

We conducted meta-analyses using Review Manager (RevMan) version 5.0 (Nordic Cochrane Centre, Cochrane Collaboration, Copenhagen, Denmark). Generic inverse variance data were combined using random effects models to obtain a summary odds ratio (OR) and 95\% confidence interval (CI) for the relationship between residential pesticide exposures (unspecified, insecticides, herbicides) and childhood leukemia by exposure time window (preconception, pregnancy, childhood). Heterogeneity across individual studies was quantified by the $I 2$ statistic ${ }^{25}$. Low, moderate, or high degrees of heterogeneity may be approximated by $I 2$ values of $25 \%, 50 \%$, and $75 \%$, respec-tively ${ }^{25}$. We conducted subgroup analyses according to total quality score ( $\geq$ median) and individual quality score components ( $>$ median for external validity and exposure measurement), study design (hospital-based or population-based case-control study), cell type (ALL, AML), location (indoor, out-door), maternal residential pesticide use (vs. household use or exposure) only, year of publication (studies published in 2000 or later only), and publication status (studies published in the peer-reviewed literature only). Where multiple exposure indices were reported per exposure time window, pesticide type, and study, sensitivity analyses were undertaken using exposure or time window definitions different from those used in the main analysis. Finally, we also examined the impact of removing studies with extreme ORs or the highest weight in analysis, as 
well as removing individual studies in a sequential manner. Because of the small number of included studies, we assessed publication bias by visual inspection of inverted funnel plots, based on the main finding from all studies ${ }^{26}$.

\section{Results}

\section{Study identification}

The results of the search strategy and study selection process are detailed in Figure 1. Of the 1,776 studies identified using our search algorithm, 112 were retained from the primary screening process. Most stud-ies were excluded during primary screening because they were irrelevant $(n=1,178)$, a duplicate record $(n=380)$, or a review article $(n=93)$. After the secondary screening process, 17 studies were retained (listed in Table 1). Major reasons for exclusion during secondary screening were irrelevance $(n=36)$, examina-tion of occupational or residential exposure to agricultural pesticides exposure only (or unclear) $(n=27)$, or a letter or editorial with no results presented $(n=14)$.

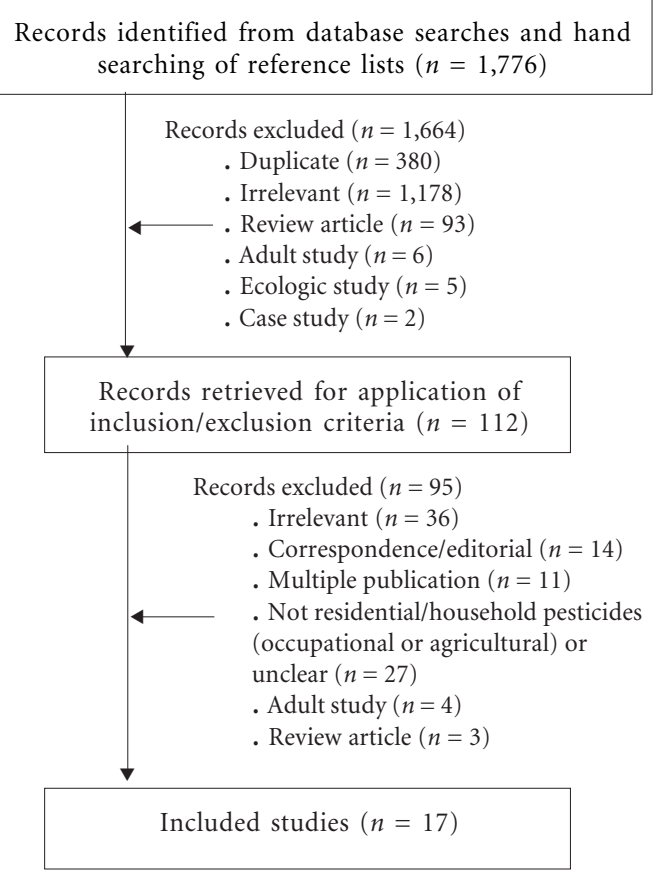

Figure 1. Study selection.

Table 1. Characteristics of included studies.

\begin{tabular}{|c|c|c|c|c|c|c|c|}
\hline $\begin{array}{l}\text { Reference, } \\
\text { country }\end{array}$ & $\begin{array}{l}\text { Cases/ } \\
\text { controls }\end{array}$ & $\begin{array}{c}\text { Case } \\
\text { definition }\end{array}$ & Age & Case recruitment & Control selection & Matching & $\begin{array}{c}\text { Participation } \\
\text { rate (cases/ } \\
\text { controls) }\end{array}$ \\
\hline \multicolumn{8}{|c|}{ Hospital-based case-control studies } \\
\hline $\begin{array}{l}\text { Schwartzbaum } \\
\text { et al. }{ }^{27} \text {, USA }\end{array}$ & $629 / 72$ & $\begin{array}{l}\text { ALL and } \\
\text { ANLL }\end{array}$ & $\begin{array}{l}4.6 \text { and } 7.4 \\
\text { median } \\
\text { years }\end{array}$ & $\begin{array}{c}\text { Admitted to St. } \\
\text { Jude's Children's } \\
\text { Research Hospital } \\
\text { 1979-1986 }\end{array}$ & $\begin{array}{c}\text { Rhabdomyosarcoma } \\
\text { cases in same } \\
\text { hospital }\end{array}$ & - & $65.8^{\mathrm{a}}$ \\
\hline $\begin{array}{l}\text { Fajardo- } \\
\text { Gutierrez et } \\
\text { al. }{ }^{28}, \text { México }\end{array}$ & $81 / 154$ & Leukemia & $\begin{array}{l}8.5-8.5 \\
\text { mean years }\end{array}$ & $\begin{array}{l}\text { Two hospitals in } \\
\text { Mexico city }\end{array}$ & $\begin{array}{l}\text { Noncancer hospital } \\
\text { and community } \\
\text { controls }\end{array}$ & Age, region & $94 / 97$ \\
\hline $\begin{array}{l}\text { Kishi et al. }{ }^{29 b} \text {, } \\
\text { Japan }\end{array}$ & $77 / 158$ & ALL & $<15$ years & $\begin{array}{c}\text { Children's Cancer } \\
\text { Registry from four } \\
\text { hospitals in } \\
\text { Hokkaido 1980- } \\
1990\end{array}$ & $\begin{array}{c}\text { Noncancer inpatients } \\
\text { in same or related } \\
\text { hospital }\end{array}$ & Age, sex & - \\
\hline Dell $^{30}$, USA & $49 / 97$ & Leukemia & $<18$ years & $\begin{array}{c}\text { Pennsylvania } \\
\text { Cancer } \\
\text { Registry from } \\
\text { Children's } \\
\text { Hospital of } \\
\text { Pittsburgh 1995- } \\
2000\end{array}$ & $\begin{array}{l}\text { Emergency depart- } \\
\text { ment }(2003) \text {, and } \\
\text { parents from Health } \\
\text { and Risk trial, and } \\
\text { convenience sample }\end{array}$ & $\begin{array}{l}\text { Age, sex, } \\
\text { race }\end{array}$ & $71 / 83$ \\
\hline
\end{tabular}


Table 1. continuation

\begin{tabular}{|c|c|c|c|c|c|c|c|}
\hline $\begin{array}{l}\text { Reference, } \\
\text { country }\end{array}$ & $\begin{array}{l}\text { Cases/ } \\
\text { controls }\end{array}$ & $\begin{array}{c}\text { Case } \\
\text { definition }\end{array}$ & Age & Case recruitment & Control selection & Matching & $\begin{array}{l}\text { Participation } \\
\text { rate (cases/ } \\
\text { controls) }\end{array}$ \\
\hline \multicolumn{8}{|c|}{ Hospital-based case-control studies } \\
\hline $\begin{array}{l}\text { Alderton et } \\
\text { al. }{ }^{8} \text {, USA/ } \\
\text { Canada }\end{array}$ & $158 / 173$ & $\begin{array}{l}\text { ALL and } \\
\text { AML with } \\
\text { Down } \\
\text { syndrome }\end{array}$ & $<20$ years & $\begin{array}{l}\text { Children's Oncology } \\
\text { Group 1997-2002 }\end{array}$ & $\begin{array}{l}\text { Physicians of Down } \\
\text { syndrome cases }\end{array}$ & Age & $75 / 81$ \\
\hline $\begin{array}{l}\text { Menegaux et } \\
\text { al. }{ }^{31} \text {, France }\end{array}$ & $280 / 288$ & $\begin{array}{l}\text { All and } \\
\text { ANLL }\end{array}$ & $<15$ years & $\begin{array}{c}\text { Hospitalized in Lille, } \\
\text { Lyon, Nancy, or } \\
\text { Paris } \\
1995-1999\end{array}$ & $\begin{array}{c}\text { Orthopedic and } \\
\text { emergency } \\
\text { department in same } \\
\text { hospital }\end{array}$ & $\begin{array}{l}\text { Age, sex, } \\
\text { ethnic origin }\end{array}$ & $99 / 99$ \\
\hline $\begin{array}{l}\text { Pombo-de- } \\
\text { Oliveira } e t \\
\text { al. } \text {. }^{32} \text {, Brazil }\end{array}$ & $202 / 440$ & IAL & $\begin{array}{l}<22 \\
\text { months }\end{array}$ & $\begin{array}{c}15 \text { institutions in } 10 \\
\text { Brazil States } \\
1999-2005\end{array}$ & $\begin{array}{l}\text { Hospitalized controls } \\
\text { with severe life- } \\
\text { threatening } \\
\text { conditions }\end{array}$ & Age & $96 / 95$ \\
\hline \multicolumn{8}{|c|}{ Population-based case-control studies } \\
\hline $\begin{array}{l}\text { Lowengart et } \\
\text { al. }{ }^{33} \text {, USA }\end{array}$ & $123 / 123$ & $\begin{array}{l}\text { ALL and } \\
\text { ANLL }\end{array}$ & $<11$ years & $\begin{array}{l}\text { Los Angeles County } \\
\text { Cancer Surveillance } \\
\text { Program 1980-1984 }\end{array}$ & $\begin{array}{l}\text { Friends of cases and } \\
\text { random digit dialing }\end{array}$ & $\begin{array}{l}\text { Age, sex, } \\
\text { race, } \\
\text { Hispanic } \\
\text { ethnicity }\end{array}$ & $79 /-$ \\
\hline $\begin{array}{l}\text { Buckley et } \\
\text { al. }{ }^{34} \text {, USA/ } \\
\text { Canada }\end{array}$ & $204 / 204$ & ANLL & $<18$ years & $\begin{array}{l}\text { Children's Cancer } \\
\text { Study Group 1980/ } \\
1984\end{array}$ & Random digit dialing & $\begin{array}{l}\text { Age, race, } \\
\text { region }\end{array}$ & $83 / 85$ \\
\hline Davis $^{35}$, USA & $71 / 85$ & ALL & $<11$ years & $\begin{array}{l}\text { Missouri Cancer } \\
\text { Registry 1985-1989 }\end{array}$ & Friends of cases & Age, sex & $96 / 97$ \\
\hline $\begin{array}{l}\text { Kishi et al. }{ }^{29 b} \text {, } \\
\text { Japan }\end{array}$ & $103 / 264$ & ALL & $<15$ years & $\begin{array}{l}\text { Children's Cancer } \\
\text { Registry from four } \\
\text { hospitals in } \\
\text { Hokkaido 1980-1990 }\end{array}$ & Same Health Region & Age, sex & - \\
\hline $\begin{array}{l}\text { Steinbuch }{ }^{36} \\
\text { USA }\end{array}$ & $271 / 322$ & AML & $<18$ years & $\begin{array}{c}\text { Children's Cancer } \\
\text { Study Group } \\
1989-1993\end{array}$ & Random digit dialing & $\begin{array}{l}\text { Age, sex, } \\
\text { region }\end{array}$ & $93 / 81$ \\
\hline $\begin{array}{l}\text { Leiss and } \\
\text { Savitz }^{37} \text {, USA }\end{array}$ & $-/ 222$ & Leukemia & $<15$ years & $\begin{array}{c}\text { Colorado Central } \\
\text { Cancer Registry } \\
1976-1983\end{array}$ & Random digit dialing & $\begin{array}{l}\text { Age, sex, } \\
\text { region }\end{array}$ & $71^{c} / 80$ \\
\hline $\begin{array}{l}\text { Meinert et } \\
\text { al. }{ }^{38} \text {, } \\
\text { Germany }\end{array}$ & $173 / 220$ & $\begin{array}{l}\text { ALL and } \\
\text { ANLL }\end{array}$ & $<15$ years & $\begin{array}{c}\text { German Childhood } \\
\text { Cancer Registry } \\
\text { 1988-1992 }\end{array}$ & $\begin{array}{l}\text { Population-weighted } \\
\text { sampling scheme, } \\
\text { local and state } \\
\text { controls }\end{array}$ & $\begin{array}{l}\text { Age, sex, } \\
\text { region }\end{array}$ & $78 / 71^{d}$ \\
\hline $\begin{array}{l}\text { Infante- } \\
\text { Rivard } \text { et } \\
\text { al. }{ }^{39} \text {, Canada }\end{array}$ & $491 / 491$ & ALL & $<10$ years & $\begin{array}{l}\text { Tertiary care centers } \\
\text { in Quebec 1980-1993 }\end{array}$ & $\begin{array}{l}\text { Family allowance } \\
\text { files }\end{array}$ & $\begin{array}{l}\text { Age, sex, } \\
\text { region }\end{array}$ & $96 / 84$ \\
\hline $\begin{array}{l}\text { Meinert et } \\
\text { al. }^{40} \text {, } \\
\text { Germany }\end{array}$ & $0,184 / 2,588$ & $\begin{array}{l}\text { ALL and } \\
\text { ANLL }\end{array}$ & $<15$ years & $\begin{array}{c}\text { German Childhood } \\
\text { Cancer Registry } \\
\text { 1992-1994, and from } \\
1980-1994 \text { for } \\
\text { nuclear installation } \\
\text { part }\end{array}$ & $\begin{array}{l}\text { Lists of local resident } \\
\text { registration offices }\end{array}$ & $\begin{array}{l}\text { Age, sex, } \\
\text { region }\end{array}$ & $77^{c} / 63$ \\
\hline $\begin{array}{l}\text { Ma et al. } .^{41} \\
\mathrm{Ma}^{42}, \text { USA }\end{array}$ & $162 / 162$ & $\begin{array}{l}\text { ALL and } \\
\text { ANLL }\end{array}$ & $<15$ years & $\begin{array}{l}\text { Major clinical } \\
\text { centers in Northern } \\
\text { California 1995-1999 }\end{array}$ & $\begin{array}{l}\text { Statewide birth } \\
\text { certificate files }\end{array}$ & $\begin{array}{l}\text { Age, sex, } \\
\text { region, } \\
\text { mother's race, } \\
\text { Hispanic } \\
\text { ethnicity }\end{array}$ & $83 / 69$ \\
\hline
\end{tabular}


Table 1. continuation

\begin{tabular}{|c|c|c|c|c|c|c|c|}
\hline $\begin{array}{l}\text { Reference, } \\
\text { country }\end{array}$ & $\begin{array}{c}\text { Cases/ } \\
\text { controls }\end{array}$ & $\begin{array}{c}\text { Case } \\
\text { definition }\end{array}$ & Age & Case recruitment & Control selection & Matching & $\begin{array}{l}\text { Participation } \\
\text { rate (cases/ } \\
\text { controls) }\end{array}$ \\
\hline \multicolumn{8}{|c|}{ Population-based case-control studies } \\
\hline $\begin{array}{l}\text { Rudant et } \\
\text { al. }{ }^{43}, \text { France }\end{array}$ & $764 / 1,681$ & $\begin{array}{l}\text { ALL and } \\
\text { AML }\end{array}$ & $<15$ years & $\begin{array}{c}\text { Pediatric oncology } \\
\text { centers and National } \\
\text { Registry of Childhood } \\
\text { Blood Malignancies } \\
\text { 2003-2004 }\end{array}$ & $\begin{array}{c}\text { National telepone } \\
\text { directory }\end{array}$ & Age, sex & $91 / 71$ \\
\hline
\end{tabular}

Abbreviations: ANLL, acute nonlymphoblastic leukemia; IAL, infantile acute leukemia. ${ }^{a}$ Overall participation rate. ${ }^{b}$ The study of Kishi etal. (1993) is presented in both table sections because results are presented in the review for both hospital- and population-based controls. 'Participation rate for all cancer cases. ${ }^{d}$ Local controls.

\section{Study characteristics}

Of the 17 identified case-control studies, 6 were hospital based, 10 were population based, and 1 reported results separately for both hospital and population controls (Table 1). Studies were conducted in the United States, Canada, Mexico, Japan, France, Brazil, and Germany. Most of the studies were published in the peer-reviewed literature; however, three doctoral dissertations presented results not published elsewhere ${ }^{30,35,36}$. Although most studies examined both ALL and acute nonlymphoblastic leukemia cases among children and adolescents up to a maximum age of 19 years, one study examined infantile acute leukemia ${ }^{32}$ and another examined both ALL and AML in children with Down syndrome 8 .

Studies varied in size, ranging from a total of 49 leukemia cases (with 7-25 cases ever exposed, depending on exposure category and time window) in the dissertation by Dell ${ }^{30}$ up to 1,184 cases (with 25-164 exposed) in the German study by Meinert et al. ${ }^{40}$. All studies conducted to date relied on parental reports of residential pesticide exposure or use inside or outside of the home, either by themselves or by profes-sional exterminators [Supplemental Material, Appendix 1 (doi:10.1289/ehp.0900966.S1)]. Although most studies assessed use of, or exposure to, pesticides or specific pesticide subgroups (insecticides, herbicides, fungicides), some studies also attempted to collect information on pesticide names and formulations or on target organism ${ }^{30,35,36,39,41}$. Nine studies considered both residential and occupational pesticide exposures s $^{29-31,33,34,36,38,40,43}$, and the remaining eight studies were exclusively residential. Five studies clearly specified (or explicitly assumed) whether residential pesticide exposure during pregnancy was attributable to maternal use ${ }^{31,33,35,41,43}$ as opposed to household use or exposure.

Virtually all studies assessed pesticide exposures during separate preconception, pregnancy, and childhood time windows; however, time window definitions differed somewhat by study (Appendix 1). Leiss and Savitz ${ }^{37}$ considered only the last 3 months of preg-nancy. Ma et al. ${ }^{41}$ considered the first 3 years of age in a separate manner. Davis $^{35}$ considered the first 6 months of age separately from the remainder of the childhood period. Some studies also combined results from different exposure time windows in analysis and reporting $36,38,40,43$.

\section{Quality assessment}

Quality scores are presented in Supplemental Material, Table 3 (doi:10.1289/ehp.0900966.S1). For hospital-based studies, total scores ranged from 7 to 12 , with a median value of 9 , of a possible maximum score of 20. For population-based studies, quality scores were higher, with a range of 9-14 and a median of 11. More recent studies tended to have higher quality scores. In assessing external validity, questions remained regarding the representativeness of subjects (both selected and participating), particularly for earlier hospital-based studies. Only Buckley et al..$^{34}$ reported that interviewers were blind to case/control status; however, the ethics of such practices have also been questioned ${ }^{39}$. Because of the self-reported nature of exposure data, no study received a point for avoidance of bias from misclassification, since the possibility for differential misclassification remained. Only Dell ${ }^{30}$ and Ma et al. ${ }^{41}$ reported results for a clearly defined preconception exposure time window. There were few data regarding frequency or duration of pesticide use, 
with most studies reporting only "ever/never" use of/exposure to the pesticide of interest. Six studies attempted to examine potential exposure-response relationships ${ }^{8,30,34,39-41}$. Although confounding is difficult to assess because there are few established risk factors for childhood leukemia, most studies examined or adjusted for at least a range of sociodemographic and maternal characteristics. Four studies, however, explicitly assessed the potential confounding influence of maternal or childhood X-ray exposure 28-30,33. $^{\text {. }}$

\section{Publication bias}

To assess the possibility of publication bias, we examined the main findings from all included studies in an inverse funnel plot [Supplemental Material, Figure 1 (doi:10.1289/ehp.0900966.S1)]. Although limited by the small number of individual studies, there was some evidence for asymmetry, with a lack of small studies found with effect sizes smaller than those from larger studies. Asymmetry may also be due to a range of other factors, including study quality, methodological differences, or the study populations per se. We attempted to identify all relevant original studies possible, including three doctoral dissertations ${ }^{30,35,36}$ and two studies published in a language other than English ${ }^{28,29}$.

\section{Data synthesis}

Of the 17 identified studies, we excluded two from the quantitative data synthesis due to a lack of $\mathrm{CIs}^{27}$ or a unique study population (Down syndrome cases only $)^{8}$. Supplemental Material, Appendix 2 (doi:10.1289/ehp.0900966.S1) lists the individual studies included in each overall and subgroup analysis by exposure time window and pesticide type.

Preconceptional household use of unspecified residential indoor ( summary OR $=1.53 ; 95 \%$ CI, $0.98-2.39 ; I 2=0 \%)$ and outdoor $(\mathrm{OR}=1.69$; 95\% CI, $1.03-2.77 ; 12=0 \%)$ pesticides was positively associated with childhood leukemia based on the two available studies ${ }^{30,41}$. We also found a significant positive association with preconceptional residential insecticide use $(\mathrm{OR}=1.92 ; 95 \%$ CI, $1.34-2.74 ; I 2=0 \%)$ in the same two studies.

Exposure to unspecified residential pesticides during pregnancy had a significant and positive association with childhood leukemia when combining results from 11 studies (OR $=1.54 ; 95 \%$ CI, $1.13-2.11 ; I 2=66 \%$ ), although the combined estimate had substantial heterogeneity (Figure 2A,
Table 2). The magnitude of the positive association increased somewhat and heterogeneity was reduced when we examined ALL only $(\mathrm{OR}=2.04$; 95\% CI, 1.54-2.68; I2 = 19\%), indoor use of unspecified pesticides $(\mathrm{OR}=1.86 ; 95 \% \mathrm{CI}, 1.25-$ $2.77 ; I 2=9 \%)$, maternal use of unspecified pesticides $(\mathrm{OR}=2.07 ; 95 \% \mathrm{CI}, 1.62-2.64 ; I 2=19 \%)$, and studies published in the peer-reviewed literature only $(\mathrm{OR}=1.81 ; 95 \% \mathrm{CI}, 1.37-2.39 ; \mathrm{I}=$ $36 \%$ ). We observed the largest OR for studies published in or since the year $2000(\mathrm{OR}=2.17$; 95\% CI, 1.85-2.53; I2=0\%).

Exposure to residential insecticides during pregnancy was associated with a significant increase in risk of childhood leukemia, when combining the results from eight studies $(\mathrm{OR}=2.05$; 95\% CI, 1.80-2.32; I2 = 0\%), with little evidence of heterogeneity (Figure 2B, Table 3 ). The summary OR changed little according to total study quality, individual quality components, hospital-versus population-based design, or publication status. The association was somewhat stronger for studies of ALL $(\mathrm{OR}=2.14 ; 95 \% \mathrm{CI}, 1.83-2.50 ; \mathrm{I} 2=$ $0 \%)$ compared with AML (OR $=1.85 ; 95 \% \mathrm{CI}$, $1.29-2.64 ; I 2=0 \%)$ and for indoor use (OR = 1.90; 95\% CI, 0.61-2.23; I2=0\%) compared with outdoor use $(\mathrm{OR}=1.54 ; 95 \% \mathrm{CI}, 0.86-2.74 ; \mathrm{I} 2=$ $36 \%)$, although they are based on fewer studies.

Exposure to residential herbicides during pregnancy also had a significant positive association with childhood leukemia $(\mathrm{OR}=1.61 ; 95 \%$ CI, $1.20-2.16 ; I 2=0 \%$ ) when combin-ing the results from five studies (Figure 2C, Table 4). Again, we observed little difference in the summary OR according to study quality, study design, or publication status. The combined relative risk estimate increased somewhat for ALL (OR = 1.73; 95\% CI, 1.28-2.35; I2 = 0).

Results for the pregnancy exposure time window were fairly robust to sensitivity analy-ses: removing studies with extreme ORs or with the highest weight or including additional studies with wide or ill-defined exposure time windows. However, removing the study of AML by Steinbuch ${ }^{36}$ from the unspecified pesticide analysis did result in a somewhat stronger association $(\mathrm{OR}=1.74$; 95\% CI, 1.36-2.24; I2 = 31\%).

Results for residential pesticide exposure during childhood were somewhat similar but were attenuated compared with those for pregnancy (Figure 3A, Table 2). We found a significant positive association between residential unspecified pesticide exposure during childhood and childhood leukemia $(\mathrm{OR}=1.38$; 95\% CI, 1.12-1.70; 12 $=4 \%$ ), with little heterogeneity. The magnitude 


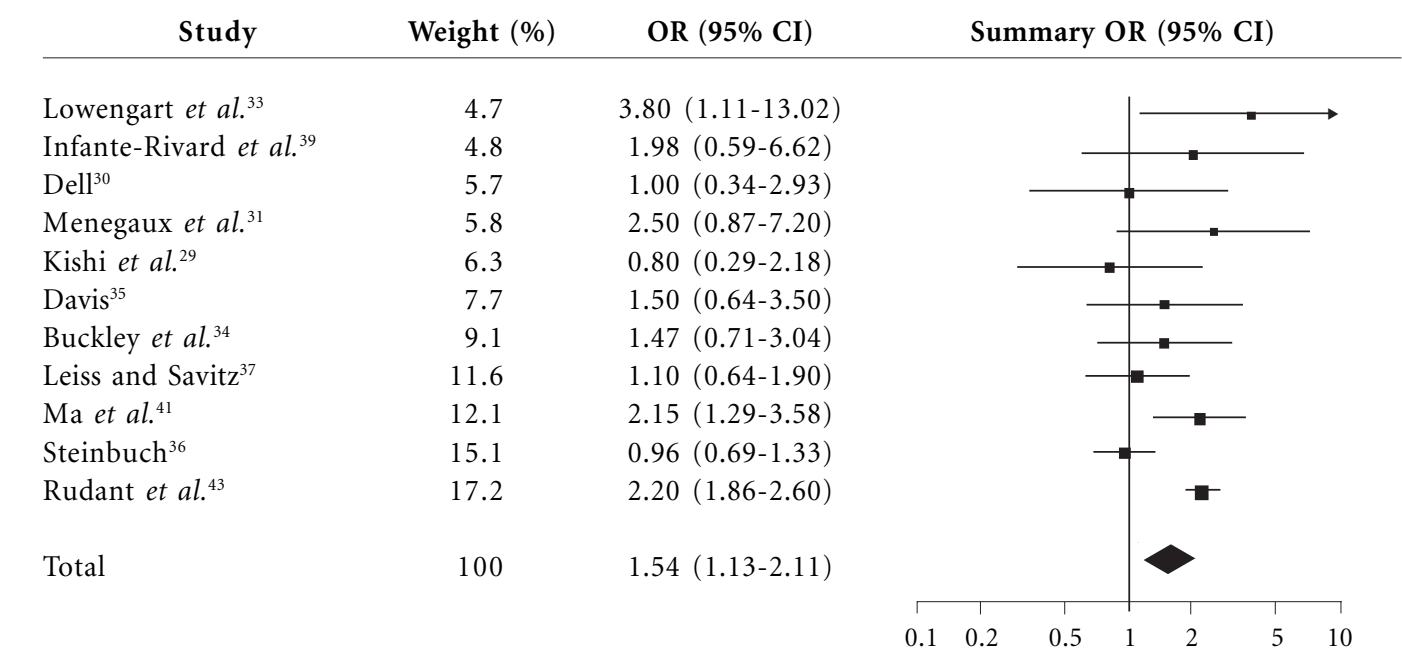

Leiss and Savitz ${ }^{37}$

Steinbuch ${ }^{36}$

$1.49(0.83-2.68)$

Ma et al. ${ }^{41}$

Menegaux et al. ${ }^{31}$

$2.12(1.29-3.49)$

Pombo-de-Oliveira et al. ${ }^{32}$

$1.80(1.16-2.80)$

Rudant et al. ${ }^{43}$

$2.18(1.61-2.95)$

$2.10(1.76-2.50)$

Total

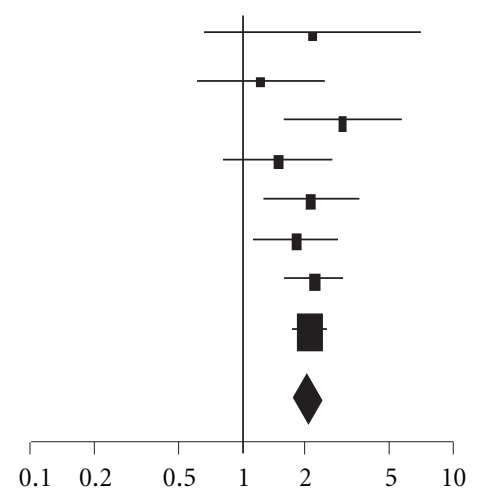

C Menegaux et al. ${ }^{31}$

Infante-Rivard et al. ${ }^{39}$

1.8

$5.90(0.67-52.00)$

Davis $^{35}$

3.2

$3.72(0.73-19.06)$

$1.50(0.68-3.30)$

Ma et al. ${ }^{41}$

13.9

$1.60(0.86-2.99)$

Rudant et al. ${ }^{43}$

58.9

$1.50(1.02-2.20)$

Total

100

$1.61(1.20-2.16)$

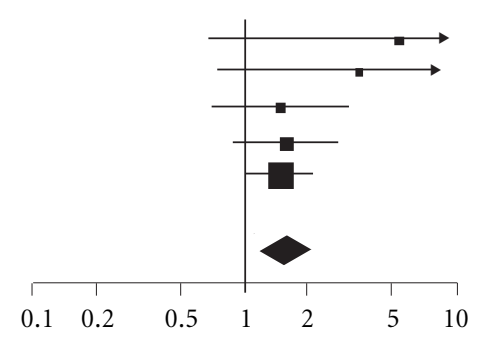

Figure 2. Analysis of the association between childhood leukemia and exposure to $(A)$ unspecified residential pesticides during pregnancy, $(B)$ residential insecticides during pregnancy, and $(C)$ residential herbicides during pregnancy. Squares indicating ORs from individual studies are proportional in size to the weight assigned to each estimate.

of the association was somewhat stronger for indoor use $(\mathrm{OR}=1.56 ; 95 \% \mathrm{CI}, 1.02-2.39 ; \mathrm{I} 2=$ $7 \%)$, studies published in or since the year 2000 $(\mathrm{OR}=1.55 ; 95 \% \mathrm{CI}, 1.14-2.12 ; \mathrm{I} 2=0 \%)$, and studies published in the peer-reviewed literature $(\mathrm{OR}=1.56 ; 95 \% \mathrm{CI}, 1.19-2.04 ; \mathrm{I} 2=0 \%)$.

Exposure to residential insecticides during childhood was also positively associated with 
Table 2. Random effects summary ORs (95\% CIs) for the relation between childhood leukemia and exposure to unspecified residential pesticides by exposure time window.

\begin{tabular}{|c|c|c|c|c|c|c|}
\hline \multicolumn{4}{|c|}{ Pregnancy } & \multicolumn{3}{|c|}{ Childhood } \\
\hline Subgroup & $\begin{array}{l}\text { Summary OR } \\
(95 \% \mathrm{CI})\end{array}$ & $\begin{array}{c}I 2 \\
(\%)\end{array}$ & $\begin{array}{c}\text { No. of } \\
\text { included } \\
\text { studies }\end{array}$ & $\begin{array}{l}\text { Summary OR } \\
\quad(95 \% \mathrm{CI})\end{array}$ & $\begin{array}{c}I 2 \\
(\%)\end{array}$ & $\begin{array}{c}\text { No. of } \\
\text { included } \\
\text { studies }\end{array}$ \\
\hline Unspecified pesticides $^{a}$ & $1.54(1.13-2.11)$ & 66 & 11 & $1.38(1.12-1.70)$ & 4 & 9 \\
\hline High total quality score & $1.56(1.08-2.27)$ & 73 & 7 & $1.40(1.05-1.85)$ & 18 & 6 \\
\hline High external validity score & $1.44(0.94-2.20)$ & 79 & 6 & $1.29(0.87-1.93)$ & 39 & 5 \\
\hline High exposure measurement score & $1.72(1.22-2.41)$ & 0 & 5 & $1.44(0.94-2.18)$ & 34 & 5 \\
\hline High confounding score & $1.66(1.05-2.63)$ & 79 & 6 & $1.48(1.14-1.93)$ & 0 & 4 \\
\hline Hospital based ${ }^{b}$ & $2.13(0.89-5.06)$ & 39 & 3 & $1.54(1.07-2.22)$ & 0 & 3 \\
\hline Population based & $1.54(1.10-2.16)$ & 71 & 9 & $1.34(1.03-1.75)$ & 17 & 7 \\
\hline $\mathrm{ALL}^{c}$ & $2.04(1.54-2.68)$ & 19 & 5 & $1.40(0.90-2.16)$ & 32 & 4 \\
\hline AML & $1.44(0.81-2.59)$ & 80 & 3 & $1.71(0.77-3.80)$ & 41 & 2 \\
\hline Indoor use & $1.86(1.25-2.77)$ & 9 & 4 & $1.56(1.02-2.39)$ & 7 & 3 \\
\hline Outdoor use & $1.50(0.98-2.32)$ & 31 & 5 & $1.40(1.05-1.87)$ & 0 & 4 \\
\hline Maternal use $^{d}$ & $2.07(1.62-2.64)$ & 19 & 5 & - & - & - \\
\hline Year published $(\geq 2000)$ & $2.17(1.85-2.53)$ & 0 & 4 & $1.55(1.14-2.12)$ & 0 & 3 \\
\hline Peer-reviewed publication & $1.81(1.37-2.39)$ & 36 & 8 & $1.56(1.19-2.04)$ & 0 & 6 \\
\hline Removing extreme ORs ${ }^{e}$ & $1.54(1.11-2.13)$ & 69 & 9 & $1.42(1.15-1.75)$ & 0 & 7 \\
\hline Removing highest weight $t^{f}$ & $1.40(1.05-1.86)$ & 34 & 9 & $1.38(1.06-1.80)$ & 16 & 8 \\
\hline $\begin{array}{l}\text { Including wide/ill-defined exposure time } \\
\text { windows }{ }^{g}\end{array}$ & $1.51(1.12-2.03)$ & 79 & 13 & $1.35(1.11-1.63)$ & 48 & 12 \\
\hline
\end{tabular}

${ }^{a}$ Where studies used multiple indices of exposure categories, the highest was selected, except for Dell ${ }^{30}$, which did not collect frequency information for all control groups. Where results were reported for leukemia overall as well as for specific cell types, the overall results were selected here. Where results were reported for indoor or outdoor pesticide use only, the indoor value was used here. Where results were reported for either owner-applied or professionally applied pesticides, the owner-applied value was used here. For Kishi et al..$^{29}$, we selected results using population controls, except for the subgroup of hospital-based studies. For Buckley et al. ${ }^{34}$, unmatched OR of 1.47 (95\% CI, 0.72-3.04) was used, calculated by collapsing the two highest exposure categories for pregnancy exposure. For the childhood time window, where studies reported results for different childhood time periods, the earliest was selected [for Ma et al. ${ }^{41}$, results for year 1 were used; for Davis ${ }^{35}$, results for 0-6 months were used; for Leiss and Savitz ${ }^{37}$, results from birth to 2 years before diagnosis were used]. ${ }^{b}$ OR for Kishi et al. ${ }^{29}$ corrected to 1.80 for hospital controls, childhood exposure. ${ }^{c}$ Using results for ALL, instead of overall leukemia, for Ma et al. ${ }^{41} .{ }^{d}$ Unmatched OR of $3.52(95 \%$ CI, 1.11-11.11) calculated from data in Lowengart et al. ${ }^{33} \cdot{ }^{e}$ Removing studies with the highest and lowest ORs. ${ }^{f}$ Removing the study (or studies, in the case where there are two with identical values) with the highest weight in analysis. ${ }^{g}$ Including studies with wide or ill-defined exposure time windows.

childhood leukemia $(\mathrm{OR}=1.61 ; 95 \% \mathrm{CI}, 1.33-$ $1.95 ; I 2=0 \%)$ when combining results from seven original studies (Figure 3B, Table 3). With restriction to studies of higher total methodological quality, the magnitude of the association was reduced and was no longer significant $(\mathrm{OR}=1.36$; 95\% CI, $0.84-2.21 ; I 2=30 \%)$. Our findings were similar when evaluating population-based studies $(\mathrm{OR}=1.48 ; 95 \% \mathrm{CI}, 1.03-2.11 ; \mathrm{I} 2=40 \%)$, studies of ALL (OR = 1.35; 95\% CI, 0.76-2.38; I2 $=51 \%)$, and studies with results for outdoor insecticide use only (OR $=1.43 ; 95 \%$ CI, 0.71-2.86; $I 2=78 \%$ ). Sensitivity analysis using an alternate exposure metric for Leiss and Savitz ${ }^{37}$ (using home extermination for insects as opposed to pest strips for insects in the home) decreased the magnitude of the association and also increased heterogeneity $(\mathrm{OR}=1.29 ; 95 \% \mathrm{CI}, 0.84-1.97 ; \mathrm{I} 2$ $=62 \%)$. ORs were elevated, however, with recent year of publication $(\mathrm{OR}=1.70 ; 95 \% \mathrm{CI}, 1.28-$ $2.27 ; I 2=0 \%)$ and among studies published in the peer-reviewed literature $(\mathrm{OR}=1.73 ; 95 \% \mathrm{CI}$, $1.41-2.12 ; I 2=0 \%)$.

Finally, we observed no association between exposure to residential herbicides during childhood and childhood leukemia when combining results for four studies overall ( $\mathrm{OR}=0.96 ; 95 \%$ CI, $0.59-1.58 ; 12=72 \%$ ) (Figure 3C, Table 4). We also observed substantial heterogeneity. Sensitivity analysis using alternate exposure indices for $\mathrm{Ma}$ et $a .^{41}$ (using year 2 of childhood as opposed to year 1) and for Davis ${ }^{35}$ (using garden herbicide use between 7 months of age and age at diagnosis as opposed to yard herbicides from 0 to 6 
Table 3. Random effects summary ORs ( $95 \%$ CIs) for the relation between childhood leukemia and exposure to residential insecticides by exposure time window.

\begin{tabular}{|c|c|c|c|c|c|c|}
\hline \multicolumn{4}{|c|}{ Pregnancy } & \multicolumn{3}{|c|}{ Childhood } \\
\hline Subgroup & $\begin{array}{l}\text { Summary OR } \\
(95 \% \mathrm{CI})\end{array}$ & $\begin{array}{l}I 2 \\
(\%)\end{array}$ & $\begin{array}{l}\text { No. of } \\
\text { included } \\
\text { studies }\end{array}$ & $\begin{array}{c}\text { Summary OR } \\
(95 \% \mathrm{CI})\end{array}$ & $\begin{array}{c}I 2 \\
(\%)\end{array}$ & $\begin{array}{c}\text { No. of } \\
\text { included } \\
\text { studies }\end{array}$ \\
\hline Insecticides $^{a}$ & $2.05(1.80-2.32)$ & 0 & 8 & $1.61(1.33-1.95)$ & 0 & 7 \\
\hline High total quality score & $2.00(1.72-2.33)$ & 0 & 5 & $1.36(0.84-2.21)$ & 30 & 4 \\
\hline High external validity score & $1.98(1.56-2.50)$ & 18 & 5 & $1.38(0.80-2.38)$ & 58 & 3 \\
\hline High exposure measurement score & $1.79(1.22-2.62)$ & 0 & 3 & $1.36(0.84-2.21)$ & 30 & 4 \\
\hline High confounding score & $2.05(1.75-2.40)$ & 0 & 4 & $1.36(0.84-2.21)$ & 30 & 4 \\
\hline Hospital based & $2.05(1.60-2.63)$ & 0 & 2 & $1.74(1.29-2.35)$ & 0 & 3 \\
\hline Population based & $2.04(1.76-2.37)$ & 0 & 6 & $1.48(1.03-2.11)$ & 40 & 4 \\
\hline $\mathrm{ALL}^{b}$ & $2.14(1.83-2.50)$ & 0 & 4 & $1.35(0.76-2.38)$ & 51 & 3 \\
\hline $\mathrm{AML}^{c}$ & $1.85(1.29-2.64)$ & 0 & 2 & - & - & - \\
\hline Indoor use only & $1.90(0.61-2.23)$ & 0 & 4 & $1.59(1.27-1.99)$ & 8 & 6 \\
\hline Outdoor use only & $1.54(0.86-2.74)$ & 36 & 4 & $1.43(0.71-2.86)$ & 78 & 3 \\
\hline Maternal use & $2.02(1.74-2.35)$ & 0 & 4 & - & - & - \\
\hline Year published (2000 and later) & $2.09(1.82-2.39)$ & 0 & 4 & $1.70(1.28-2.27)$ & 0 & 3 \\
\hline Peer-reviewed publication & $2.12(1.86-2.42)$ & 0 & 6 & $1.73(1.41-2.12)$ & 0 & 5 \\
\hline Removing extreme $\mathrm{ORs}^{d}$ & $2.05(1.80-2.34)$ & 0 & 6 & $1.72(1.40-2.11)$ & 0 & 5 \\
\hline Removing highest weight ${ }^{e}$ & $1.98(1.64-2.39)$ & 0 & 7 & $1.47(1.01-2.13)$ & 19 & 5 \\
\hline Including unspecified, indoor pesticides ${ }^{f}$ & $2.02(1.78-2.29)$ & 0 & 11 & $1.63(1.35-1.98)$ & 0 & 11 \\
\hline $\begin{array}{l}\text { Including wide/ill-defined exposure time } \\
\text { windows }{ }^{g}\end{array}$ & $1.81(1.48-2.21)$ & 46 & 10 & $1.44(1.25-1.67)$ & 15 & 8 \\
\hline
\end{tabular}

${ }^{a}$ Where studies used multiple indices of exposure categories, the highest was selected, except for Dell ${ }^{30}$, which did not collect frequency information for all control groups. Where results were reported for leukemia overall as well as for specific cell types, the overall results were selected here. Where results were reported for indoor or outdoor insecticide use only, the indoor value was used. Where results were reported for either owner-applied or professionally applied insecticides, the owner-applied value was used here. For Pombo-de-Oliveira et al. ${ }^{32}$, personal correspondence with the study author (13 March 2008) corrected the upper CI reported in the published article from 2.13 to 2.95 and confirmed that pesticide exposure was mainly insecticide exposure. For the childhood time window, where studies reported results for different childhood time periods, the earliest was selected [for Ma et al. ${ }^{41}$, results for year 1 used; for Davis ${ }^{35}$, results for 0-6 months used here; for Leiss and Savitz ${ }^{37}$, results from birth to 2 years before diagnosis used here]. For Fajardo-Gutierrez et al. ${ }^{28}$, personal correspondence with the study author (28 May 2008) confirmed exposure was postnatal exposure to insecticides in the home. ${ }^{b}$ Using results for ALL, instead of overall leukemia, for Ma et al..$^{41}$ and Rudant et al. ${ }^{43}$. ${ }^{C}$ Using results for AML, instead of overall leukemia, for Rudant et al. ${ }^{43} .{ }^{d}$ Removing studies with the highest and lowest OR. ${ }^{e}$ Removing the study (or studies, in the case where there are two with identical values) with the highest weight in analysis. ${ }^{f}$ Including studies that reported indoor unspecified pesticide use. ${ }^{g}$ Including studies with wide or ill-defined exposure time windows.

months of age) resulted in a summary OR for childhood leukemia of 1.38 (95\% CI, 1.10-1.72; $I 2=0 \%)$.

\section{Discussion}

In this meta-analysis, we examined previous observational epidemiologic studies of the association between residential pesticide exposure during critical exposure time windows (preconception, pregnancy, childhood) and childhood leukemia. Overall, exposure to residential pesticides during pregnancy was positively associated with childhood leukemia. We observed the strongest association for insecticides, with little evidence of heterogeneity. Results for childhood exposures were less clear. Although we observed overall positive and significant associations for exposure to unspecified pesticides and insecticides during childhood, for insecticides the association attenuated among studies with higher total methodological quality. Few studies examined childhood exposure to herbicides, and we observed no overall positive association. Although we also examined preconceptional residential pesticide exposure, only two studies had clearly defined exposure time windows on which to base an assess-ment of the effect of this type of exposure on childhood leukemia. We obtained some differences in results in subgroup analysis according to study quality, study design, and publication status or when us- 
Table 4. Random effects summary ORs (95\% CIs) for the relation between childhood leukemia and exposure to residential herbicides by exposure time window.

\begin{tabular}{|c|c|c|c|c|c|c|}
\hline \multicolumn{4}{|c|}{ Pregnancy } & \multicolumn{3}{|c|}{ Childhood } \\
\hline Subgroup & $\begin{array}{c}\text { Summary OR } \\
(95 \% \mathrm{CI})\end{array}$ & $\begin{array}{c}I 2 \\
(\%)\end{array}$ & $\begin{array}{c}\text { No. of } \\
\text { included } \\
\text { studies }\end{array}$ & $\begin{array}{c}\text { Summary OR } \\
(95 \% \mathrm{CI})\end{array}$ & $\begin{array}{c}I 2 \\
(\%)\end{array}$ & $\begin{array}{c}\text { No. of } \\
\text { included } \\
\text { studies }\end{array}$ \\
\hline Herbicides $^{a}$ & $1.61(1.20-2.16)$ & 0 & 5 & $0.96(0.59-1.58)$ & 72 & 4 \\
\hline High total quality score & $1.57(1.17-2.11)$ & 0 & 4 & $0.81(0.40-1.64)$ & 80 & 3 \\
\hline High external validity score & $1.56(1.11-2.18)$ & 0 & 3 & $0.81(0.24-2.77)$ & 85 & 2 \\
\hline High exposure measurement score & $1.68(1.05-2.68)$ & 0 & 3 & $0.81(0.40-1.64)$ & 80 & 3 \\
\hline High confounding score & $1.58(1.15-2.18)$ & 0 & 3 & $1.04(0.52-2.05)$ & 80 & 2 \\
\hline Population based & $1.57(1.17-2.11)$ & 0 & 4 & $0.81(0.40-1.64)$ & 80 & 3 \\
\hline $\mathrm{ALL}^{b}$ & $1.73(1.28-2.35)$ & 0 & 4 & $0.85(0.43-1.66)$ & 78 & 3 \\
\hline Maternal use & $1.54(1.12-2.12)$ & 0 & 4 & - & - & - \\
\hline Year published (2000 and later) & $1.57(1.14-2.17)$ & 0 & 3 & $0.99(0.50-1.96)$ & 68 & 2 \\
\hline Peer-reviewed publication & $1.62(1.18-2.23)$ & 0 & 4 & $1.16(0.77-1.75)$ & 61 & 3 \\
\hline Removing extreme ORs ${ }^{c}$ & $1.68(1.05-2.68)$ & 0 & 3 & $0.99(0.50-1.96)$ & 68 & 2 \\
\hline Removing highest weight ${ }^{d}$ & $1.77(1.12-2.80)$ & 0 & 4 & $0.79(0.40-1.53)$ & 68 & 3 \\
\hline Including unspecified, outdoor pesticides ${ }^{e}$ & $1.56(1.23-1.99)$ & 0 & 8 & $1.06(0.73-1.52)$ & 60 & 6 \\
\hline $\begin{array}{l}\text { Including wide/ill-defined exposure time } \\
\text { windows }\end{array}$ & - & - & - & $1.14(0.94-1.39)$ & 56 & 9 \\
\hline
\end{tabular}

${ }^{a}$ Where studies used multiple indices of exposure categories, the highest was selected, except for Dell ${ }^{30}$, which did not collect frequency information for all control groups. Where results were reported for leukemia overall as well as for specific cell types, the overall results were selected here. For the childhood time window, where studies reported results for different childhood time periods, the earliest was selected [for Ma et al. ${ }^{41}$, results for year 1 used here; for Davis ${ }^{35}$, results for $0-6$ months]. ${ }^{b}$ Using results for ALL, instead of overall leukemia, for Ma et al. ${ }^{41}$ and Rudant $e t a l .{ }^{43} .{ }^{c}$ Removing studies with the highest and lowest OR. ${ }^{d}$ Removing the study (or studies, in the case where there are two with identical values) with the highest weight in analysis. ${ }^{e}$ Including studies that reported outdoor unspecified pesticide use. For Leiss and Savitz ${ }^{37}$, the earliest time window from birth to 2 years before diagnosis used for childhood analysis. ${ }^{f}$ Including studies with wide of ill-defined exposure time windows.

ing alternate exposure indices for some of the associations we observed.

Previous reviews have concluded that there is likely to be a positive association between pesticide exposure and childhood leukemia ${ }^{15,44}$. Results from a companion article revealed positive associations between childhood leukemia and prenatal maternal occupational exposure to pesticides $^{20}$. Occupational pesticide exposures are of greater magnitude compared with those from other sources ${ }^{45-47}$. Summary ORs for the relation between prenatal maternal occupational exposure to pesticides and childhood leukemia were larger compared with those here, with an overall summary OR of 2.08 (95\% CI, 1.51-2.88), reported for any pesticide exposure, and $2.72(95 \%$ CI, 1.47-5.04), reported for insecticide exposure, lending further credibility to the hypothesis.

Among the potential limitations of the present analysis is the possibility for publica-tion bias. Although such bias can be difficult to assess, we found several small studies that were either unpublished (PhD dissertations) $)^{30,35,36}$ or written in languages other than English ${ }^{28,29}$. The magnitude of the association observed between unspecified pesticides and childhood leukemia tended to strengthen, and the heterogeneity reduce, on restriction to studies published in the peer-reviewed literature only.

Original studies may be subject to limitations related to exposure assessment and reporting. Typically, the quality of environ-mental epidemiology studies is influenced by the quality of exposure measurement ${ }^{48}$. The studies in the present meta-analysis measured residential pesticide exposure entirely by parental report, and only in some instances were detailed data collected on specific types of pesticides or frequency of use. Although based on small numbers of exposed subjects, some limited evidence supports a positive exposure-response relation-ship between childhood leukemia and both pregnancy and childhood household pesticide or insecticide exposure $e^{8,34,39,41}$. Although there may be dif-ferential misclassification of exposure among cases, it has also been suggested that nondif-ferential misclas- 


\begin{tabular}{|c|c|c|}
\hline Study & Weight (\%) & OR $(95 \% \mathrm{CI})$ \\
\hline Buckley et al. ${ }^{34}$ & 2.2 & $3.50(0.89-13.80)$ \\
\hline Infante-Rivard et al. ${ }^{39}$ & 5.2 & $2.27(0.93-5.55)$ \\
\hline Kishi et al. ${ }^{29}$ & 6.0 & $1.25(0.55-2.86)$ \\
\hline Dell $^{30}$ & 7.7 & $1.12(0.54-2.32)$ \\
\hline Davis $^{35}$ & 8.5 & $0.80(0.40-1.60)$ \\
\hline Leiss and Savitz ${ }^{37}$ & 8.5 & $0.90(0.45-1.80)$ \\
\hline Ma et al. ${ }^{41}$ & 15.1 & $1.63(0.98-2.72)$ \\
\hline Menegaux et al..$^{31}$ & 18.2 & $1.70(1.07-2.70)$ \\
\hline Steinbuch ${ }^{36}$ & 28.7 & $1.36(0.95-1.95)$ \\
\hline Total & 100 & $1.38(1.12-1.70)$ \\
\hline Dell $^{30}$ & 0.5 & $2.00(0.13-31.97)$ \\
\hline Infante-Rivard et al. ${ }^{39}$ & 3.9 & $2.08(0.78-5.52)$ \\
\hline Fajardo-Gutierrez et al..$^{28}$ & 9.4 & $1.85(0.99-3.47)$ \\
\hline Davis $^{35}$ & 9.4 & $0.80(0.43-1.50)$ \\
\hline Ma et al. ${ }^{41}$ & 14.0 & $1.70(1.01-2.85)$ \\
\hline Leiss and Savitz ${ }^{37}$ & 31.4 & $1.70(1.20-2.40)$ \\
\hline Menegaux et al..$^{31}$ & 31.4 & $1.70(1.20-2.40$ \\
\hline Total & 100 & $1.61(1.33-1.95)$ \\
\hline
\end{tabular}

Summary OR (95\% CI) 
trichloroethane) or its metabolite DDE (dichlorodiphenyldichloroethylene), methoxychlor, or pentachlorophenol concentrations.

Studies differed in the precise exposure time windows captured and reported. Some studies reported results only for all time windows combined, which may obscure the potential association linked to specific exposure time windows; however, because high correlations have been found between pesticide exposures in different exposure time windows ${ }^{8,34}$, the extent to which such obfuscation might occur is difficult to determine. Sensitivity analyses that included studies reporting results in wide or ill-defined exposure time windows tended to increase the degree of heterogeneity we observed, as quantified by the $I 2$ statistic. In models comparing pesticide exposures occurring during pregnancy, in childhood, and in both pregnancy and childhood, Menegaux et al. ${ }^{31}$ observed the strongest associations with childhood leukemia when exposures were experienced during both exposure time windows, as opposed to during one exposure time window only.

Exposure to different types of pesticides may also be correlated, and few studies have attempted to disentangle the independent effects of specific pesticides. Menegaux et al. ${ }^{31}$ incorporated different insecticide exposures simultaneously and found that the positive associations remained. Lowengart et al. ${ }^{33}$ reported that the positive associations observed for parental exposure to either household pesticides or garden pesticides/herbicides during pregnancy remained after mutual adjustment. Davis ${ }^{35}$ reported little change in pesticide ORs after adjustment for other pesticide use. However, Rudant et al. ${ }^{43}$ reported that associations with paternal pesticide use were confounded by maternal use. Residential pesticides also represent only one potential pathway through which parental or childhood pesticide exposure may occur, with food, occupation, and the transport of agricultural pesticides representing other potentially important exposure pathways ${ }^{52-56}$. Among studies of residential pesticides that also collected data on maternal occupational pesticide exposures, the prevalence of occupational pesticide exposure was low, and there is little information on the potential interrelationships of occupational and residential pesticide exposures for childhood leukemia. However, Rudant et al. ${ }^{43}$ reported that excluding children with occupationally exposed parents did not change results, and Buckley et al. ${ }^{34}$ reported that the positive associations observed for residential pesticide exposure remained in multivariate models containing pa- rental occupational pesticide exposure. Residential pesticides may be an important exposure source even in agricultural areas ${ }^{57}$.

In terms of other potential confounding variables, as noted above, most studies examined or adjusted for at least a range of sociodemographic and maternal characteristics. Leiss and Savitz ${ }^{37}$ also considered magnetic field exposure. Menegaux et al. ${ }^{31}$ examined early common infections, child care attendance, and residence near a gas station/garage as potential confounders, with no change in results. Rudant et $a l^{43}$ also reported that early infections and daycare attendance did not change results for residential pesticides. Lowengart et al. ${ }^{33}$ reported that the positive associations observed for both residential pesticide exposure and paternal occupational exposure to chlorinated solvents remained after mutual adjustment. Among the studies that assessed the potential influence of maternal or childhood Xray exposures, Lowengart et al. ${ }^{33}$ and FajardoGutierrez et al. ${ }^{28}$ reported no change in findings; however, Dell ${ }^{30}$ reported that the positive association observed between pregnancy exposure to yard pesticides and childhood leukemia disappeared after adjusting for maternal X-ray exposure and use of antibiotics during pregnancy.

For childhood leukemia, the pregnancy exposure time window may be of particular importance ${ }^{10}$. Most childhood leukemia cases occur in the first few years of life ${ }^{3}$. Most childhood leukemia cases have gross chromosomal abnormalities, including translocations; however, little is known regarding their underlying cause ${ }^{58}$. A study of routinely collected blood samples in neonates revealed leukemia clones with specific chromosomal translocations in children who later developed ALL ${ }^{59}$. Preleukemic clones may persist throughout childhood and may require postnatal exposures for leukemia progression ${ }^{60}$. In a small study of infants born in an agricultural region in the Philippines, the prevalence of a common AML translocation $[t(8 ; 21)]$ in cord blood samples was about 2-fold higher among those with detectable meconium levels of the methylcarbamate insecticide propoxur ${ }^{61,62}$. The prenatal origin of AML may be less frequent than that of ALL ${ }^{63}$.

\section{Conclusions}

This systematic review and meta-analysis reveals positive associations between exposure to residential pesticides in pregnancy and childhood and childhood leukemia, with the strongest associa- 
tions observed for insecticides. Further work is needed to confirm previous findings based on self-report, to better describe potential exposureresponse relationships, to assess specific pesticides and toxicologically related subgroups of pesticides in more detail, and to assess the potential role of preconceptional paternal exposures. Large prospective studies of children with biomonitoring data and discovery of biomarkers of past exposure (especially for rapidly excreted pesticides) would aid in this regard ${ }^{64}$. Ad- ditional studies are needed in order to better understand potential mechanisms of action and gene-pesticide interactions. In terms of precautionary public health implications, cosmetic pesticide bylaws implemented in various Canadian jurisdictions typically do not address the use of pesticides indoors or for essential purposes, such as to intervene in a health hazard or infestation to property. Further consideration of the need to reduce prenatal and childhood exposure to residential pesticides may be warranted.

Appendix 1. Definitions of exposure time windows reported in individual studies.

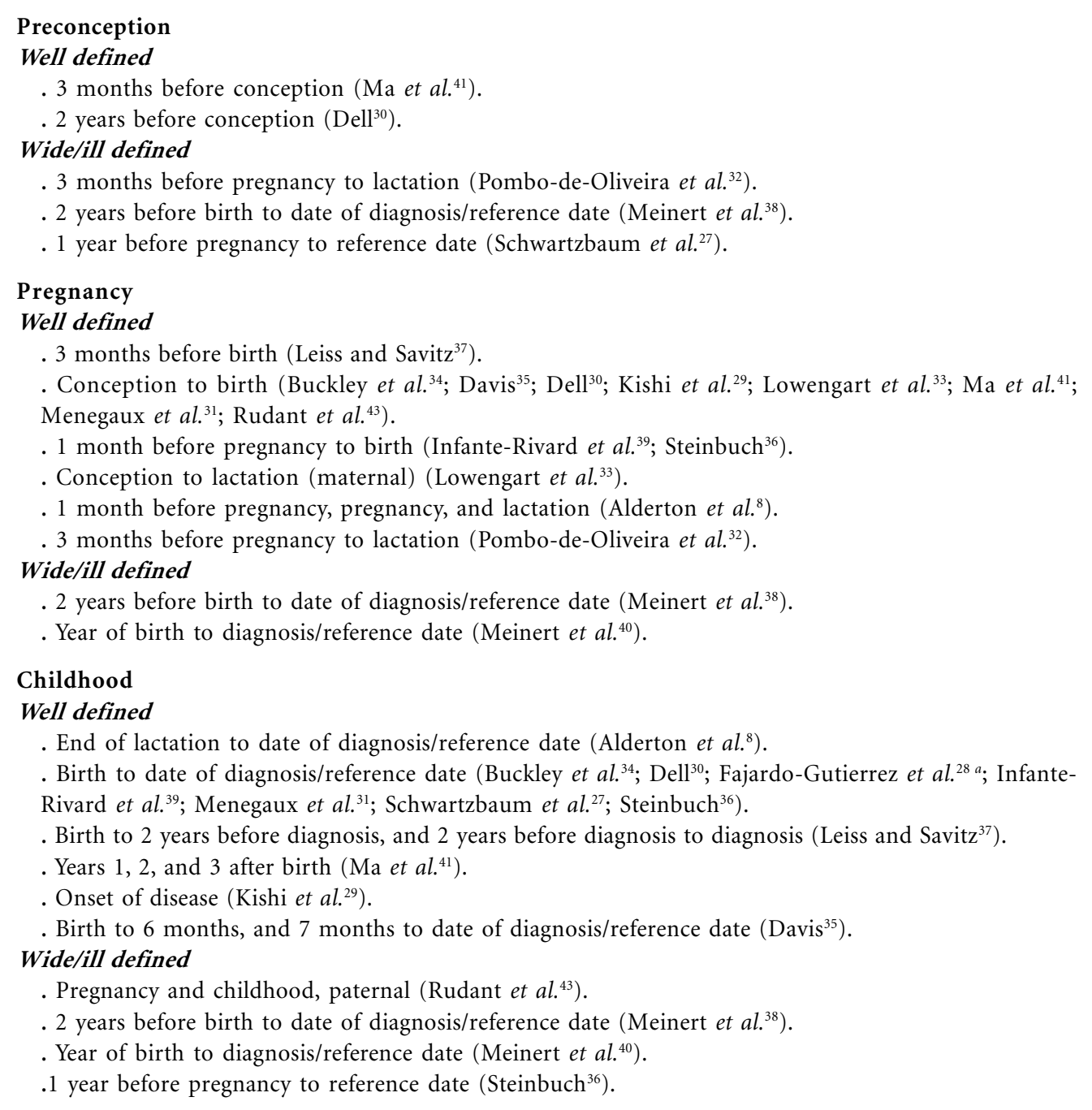

${ }^{a}$ Mejia-Arangure JM, personal communication. 


\section{Acknowledgements}

We thank D. Salzwedel for assistance in developing the literature search strategy. This review was funded in part by a financial contribution from the Public Health Agency of Canada through the National Collaborating Centre for Environmental Health. M Turner holds a Canada graduate scholarship from the Canadian Institutes of Health Research. The views expressed herein do not necessarily represent the views of the Public Health Agency of Canada or the National Collaborating Centre for Environmental Health. D Krewski is chief executive officer and chief risk scientist for Risk Sciences International (http:// www.risksciencesint.com). The other authors declare they have no competing financial interests.

\section{References}

1. American Cancer Society. Cancer facts and figures, 2009. Atlanta, GA: American Cancer Society; 2009.

2. Canadian Cancer Society/National Cancer Institute of Canada. Canadian cancer statistics 2009. Toronto: Canadian Cancer Society; 2009.

3. Agha M, BiMonte B, Greenberg M, Greenberg C, Barr R, McLaughlin J. Incidence trends and projections for childhood cancer in Ontario. Int J Cancer 2006; 118:2809-2815.

4. MacArthur A, Spinelli J, Rogers P, Goddard K, Abanto Z, McBride M. Mortality among 5-year survivors of cancer diagnosed during childhood or adolescence in British Columbia, Canada. Pediatr Blood Cancer 2007; 48:460-467.

5. Speechley K, Barrera M, Shaw A, Morrison H, Maunsell E. Health-related quality of life among child and adolescent survivors of childhood cancer. J Clin Oncol 2006; 24:2536-2543.

6. Greaves M. Childhood leukaemia. BMJ 2002; 324:283-287.

7. Rossig C, Juergens H. Aetiology of childhood acute leukaemias: current status of knowledge. Radiat Prot Dosimetry 2008; 132:114-118.

8. Alderton LE, Spector LG, Blair CK, Roesler M, Olshan AF, Robison LL, Ross JA. Child and maternal household chemical exposure and the risk of acute leukemia in children with Down's syndrome: a report from the Children's Oncology Group. Am J Epidemiol 2006; 164:212-221.

9. Ross JA, Spector LG, Robison LL, Olshan AF. Epidemiology of leukemia in children with Down's syndrome. Pediatr Blood Cancer 2005; 44:8-12.

10. Belson M, Kingsley B, Holmes A. Risk factors for acute leukemia in children: a review. Environ Health Perspect 2007; 115:138-145.

11. Greaves M. Infection, immune responses and the aetiology of childhood leukaemia. Nat Rev Cancer 2006; 6:193-203.

12. Infante-Rivard C, El-Zein M. Parental alcohol consump-tion and childhood cancers: a review. $J$ Toxicol Environ Health B 2007; 10:101-129.

13. Lee KM, Ward MH, Han S, Ahn HS, Kang HJ, Choi HS, Shin HY, Koo HH, Seo JJ, Choi JE, Ahn YO, Kang D. Paternal smoking, genetic polymorphisms in CYP1A1 and childhood leukemia risk. Leuk Res 2009; 33:250-258.

14. Schuz J, Ahlbom A. Exposure to electromagnetic fields and the risk of childhood leukaemia: a review. Radiat Prot Dosimetry 2008; 132:202-211.

15. Infante-Rivard $C$, Weichenthal S. Pesticides and childhood cancer: an update of Zahm and Ward's 1998 review. J Toxicol Environ Health B 2007; 10:81-99.

16. Arya N. Pesticides and human health: why public health officials should support a ban on non-essential residential use. Can J Public Health 2005; 96:89-92.

17. Ontario Ministry of the Environment. Implementing the Cosmetic Pesticides Ban Proposed. New Regulation. 2008. [accessed 11 May 2009]. Available: http://www.ene.gov.on.ca/en/land/pesticides/ Factsheet-pesticides.pdf 
18. Lu C, Barr DB, Pearson MA, Walker LA, Bravo R. The attribution of urban and suburban children's exposure to synthetic pyrethroid insecticides: a longitudinal assessment. J Expo Sci Environ Epidemiol 2009; 19:69-78.

19. Lu C, Knutson DE, Fisker-Andersen J, Fenske RA. Biological monitoring survey of organophosphorus pesticide exposure among preschool children in the Seattle metropolitan area. Environ Health Perspect 2001; 108:299-303.

20. Wigle DT, Turner MC, Krewski D. A systematic review and meta-analysis of childhood leukemia and parental occupational pesticide exposure. Environ Health Perspect 2009; 117:1505-1513.

21. Ovid. 2009. [accessed 31 March 2009]. Available: http://gateway.ovid.com

22. National Library of Medicine. TOXNET (Toxicology Data Network). 2009. [accessed 31 March 2009]. Available: http://toxnet.nlm.nih.gov

23. Proquest. ProQuest Digital Dissertations and Theses. 2009. [accessed 31 March 2009]. Available: http:/ /proquest.umi.com/login.23.

24. Downs SH, Black N. The feasibility of creating a checklist for the assessment of the methodological quality both of randomised and non-randomised studies of health care interventions. J Epidemiol Community Health 1998; 52:377-384.

25. Higgins J, Thompson S, Deeks J. Measuring inconsistency in meta-analyses. BMJ 2003; 327:557-560.

26. Ioannidis J, Trikalinos T. The appropriateness of asymmetry tests for publication bias in meta-analyses a large survey. CMAJ 2007; 176:1091-1096.

27. Schwartzbaum JA, George SL, Pratt CB, Davis B. An exploratory study of environmental and medical factors potentially related to childhood cancer. Med Pediatr Oncol 1991; 19:115-121.

28. Fajardo-Gutierrez A, Garduno-Espinosa J, Yamamoto-Kimura L, Hernandez-Hernandez DM, Mejia-Arangure M, Gomez-Delgado A, Farfan-Canto JM, Ortiz-Fernandez A, Martinez-Garcia MDC. [Risk factors associated with the development of leukemia in children] [in Spanish]. Bol Med Hosp Infant Mex 1993; 50:248-257.

29. Kishi R, Katakura Y, Yuasa J, Miyake H. [Association of parents' occupational exposure to cancer in children: a case-control study of acute lymphoblastic leukemia] [in Japanese]. Sangyo Igaku 1993; 35:515-529.

30. Dell DM. Epidemiology of childhood leukemia: environmental and genetic determinants $[\mathrm{PhD}$ dissertation]. Pittsburgh, PA: University of Pittsburgh; 2004.

31. Menegaux F, Baruchel A, Bertrand Y, Lescoeur B, Leverger G, Nelken B, Sommelet D, Hémon D, Clavel J. Household exposure to pesticides and risk of childhood acute leukaemia. Occup Environ Med 2006; 63:131-134.
32. Pombo-de-Oliveira MS, Koifman S, Brazilian Collaborative Study Group of Infant Acute Leukemia. Infant acute leukemia and maternal exposures during pregnancy. Cancer Epidemiol Biomarkers Prev 2006; 15:2336-2341.

33. Lowengart RA, Peters JM, Cicioni C, Buckley J, Bernstein L, Preston-Martin S, Rappaport E. 1987. Childhood leukemia and parents' occupational and home exposures. J Natl Cancer Inst 1987; 79:39-46.

34. Buckley JD, Robison LL, Swotinsky R, Garabrant DH, LeBeau M, Manchester P, Nesbit ME, Odom L, Peters JM, Woods WG. Occupational exposures of parents of children with acute nonlymphocytic leukemia: a report from the Childrens Cancer Study Group. Cancer Res 1989; 49:4030-4037.

35. Davis JR. Childhood cancer and pesticide use in the home, garden, and yard [PhD dissertation]. Berkeley, CA: University of California, Berkeley; 1991.

36. Steinbuch M. The role of environmental exposures in the etiology of childhood acute myeloid leukemia [PhD dissertation]. Columbus, OH: Ohio State University; 1994.

37. Leiss JK, Savitz DA. Home pesticide use and childhood can-cer: a case-control study. Am J Public Health 1995; 85:249-252.

38. Meinert R, Kaatsch P, Kaletsch U, Krummenauer F, Miesner A, Michaelis J. Childhood leukaemia and exposure to pesticides: results of a case-control study in northern Germany. Eur J Cancer 1996; 32A:19431948.

39. Infante-Rivard C, Labuda D, Krajinovic M, Sinnett D. Risk of childhood leukemia associated with exposure to pesticides and with gene polymorphisms. Epidemiology 1999; 10:481-487.

40. Meinert R, Schuz J, Kaletsch U, Kaatsch P, Michaelis J. Leukemia and non-Hodgkin's lymphoma in childhood and exposure to pesticides: results of a register-based case-control study in Germany. Am J Epidemiol 2000; 151:639-650.

41. Ma X, Buffler PA, Gunier RB, Dahl G, Smith MT, Reinier K, Reynolds P. Critical windows of exposure to household pesticides and risk of childhood leukemia. Environ Health Perspect 2002; 110:955-960.

42. Ma X. Environmental and genetic factors in the etiology of childhood leukemia [PhD dissertation]. Berkeley, CA: University of California, Berkeley; 2001.

43. Rudant J, Menegaux F, Leverger G, Baruchel A, Nelken B, Bertrand Y, Patte C, Pacquement H, Vérité C, Robert A, Michel G, Margueritte G, Gandemer V, Hémon D, Clavel J. Household exposure to pesticides and risk of childhood hematopoietic malignancies: the ESCALE study (SFCE). Environ Health Perspect 2007; 115:1787-1793.

44. Daniels JL, Olshan AF, Savitz DA. Pesticides and childhood cancers. Environ Health Perspect 1997; 105:1068-1077. 
45. Bradman A, Eskenazi B, Barr DB, Bravo R, Castorina R, Chevrier J, Kogut K, Harnly ME, McKone TE. Organophosphate urinary metabolite levels during pregnancy and after delivery in women living in an agricultural community. Environ Health Perspect 2005; 113:1802-1807.

46. Mandel J, Alexander B, Baker B, Acquavella J, Chapman P, Honeycutt R. Biomonitoring for farm families in the farm family exposure study. Scand J Work Environ Health 2005; 31(Suppl.1):98-104.

47. Sala M, Sunyer J, Otero R, Santiago-Silva M, Ozalla D, Herrero C, To-Figueras J, Kogevinas M, Anto JM, Camps C, Grimalt J. Health effects of chronic high exposure to hexachlorobenzene in a general population sample. Arch Environ Health 1999; 54:102-109.

48. Hertz-Picciotto I. Environmental epidemiology. In: Rothman K, Greenland S, editors. Modern epidemiology. Philadelphia: Lippincott Williams \& Wilkins; 1998. p. 555-584.

49. Infante-Rivard C, Jacques L. Empirical study of parental recall bias. Am J Epidemiol 2000; 152:480-486.

50. Arbuckle T, Cole DC, Ritter L, Ripley B. Farm children's exposure to herbicides: comparison of biomonitoring and questionnaire data. Epidemiology 2004; 5:187-194.

51. Perry M, Marbella A, Layde P. Nonpersistent pesticide exposure self-report versus biomonitoring in farm pesticide applicators. Ann Epidemiol 2006; 16:701-707.

52. Ward MH, Colt JS, Metayer C, Gunier RB, Lubin J, Crouse V, Nishioka MG, Reynolds P, Buffler PA. Residential exposure to polychlorinated biphenyls and organochlorine pesticides and risk of childhood leukemia. Environ Health Perspect 2009; 117:1007-1013.

53. Lu C, Toepel K, Irish R, Fenski R, Barr DB, Bravo R. Organic diets significantly lower children's dietary exposure to organophosphorus pesticides. Environ Health Perspect 2008; 114:260-263.

54. National Research Council. Pesticides in the diets of infants and children. Washington, DC: National Academy Press; 1993.

55. Reynolds P, Von Behren J, Gunier RB, Goldberg DE, Harnly M, Hertz A. Agricultural pesticide use and childhood cancer in California. Epidemiology 2005; 16:93-100.

56. Ritz B, Rull RP. Assessment of environmental exposures from agricultural pesticides in childhood leukaemia studies: challenges and opportunities. Radiat Prot Dosimetry 2008; 132:148-155.

57. Quandt SA, Arcury TA, Rao P, Snively BM, Camann DE, Doran AM, Yau AY, Hoppin JA, Jackson DS. Agricultural and residential pesticides in wipe samples from farmworker family residences in North Carolina and Virginia. Environ Health Perspect 2004; 112:382-387.
58. Wiemels JL. Chromosomal translocations in childhood leukemia: natural history, mechanisms, and epidemiology. J Natl Cancer Inst Monogr 2008; 39:8790 .

59. Gale KB, Ford AM, Repp R, Borkhardt A, Keller C, Eden OB, Greaves MF. Backtracking leukemia to birth: identification of clonotypic gene fusion sequences in neonatal blood spots. Proc Natl Acad Sci USA 1997; 94:13950-13954.

60. Maia A, Koechling J, Corbett R, Metzler M, Wiemels JL, Greaves M. Protracted postnatal natural histories in childhood leukemia. Genes Chromosomes Cancer 2004; 39:335-340.

61. Lafiura KM, Bielawski DM, Posecion NC Jr, Ostrea EM Jr, Matherly LH, Taub JW, Ge Y. Association between pre-natal pesticide exposures and the generation of leukemia-associated T(8;21). Pediatr Blood Cancer 2007; 49:624-628.

62. Raimondi S, Chang M, Ravindranath Y, Behm F, Gresik MV, Steuber C, Steuber CP, Weinstein HJ, Carroll AJ. Chromosomal abnormalities in 478 children with acute myeloid leukemia: clinical characteristics and treatment outcome in a cooperative pediatric oncology group study-POG 8821. Blood 1999; 94:3707-3716.

63. Burjanivova T, Madzo J, Muzikova K, Meyer C, Schneider B, Votava F, Marschalek R, Stary J, Trka J, Zuna J. Prenatal origin of childhood AML occurs less frequently than in childhood ALL. BMC Cancer 2006; 6:100. [Review in Internet], [cited 2006 April 21]. Doi:10.1186/1471-2407-6-100.

64. Metayer C, Buffler PA. Residential exposures to pesticides and childhood leukaemia. Radiat Prot Dosimetry 2009; 132:212-219.

Received 11 May 2009

Accepted 29 July 2009 